\title{
Credit Information Sharing and Credit Risk Reduction in Kenya Commercial Banks
}

\author{
Tabitha Nasieku \\ Lecturer \\ School of Business \\ Department of Economics, Finance and Accounting \\ Jomo Kenyatta University of Agriculture and Technology \\ Email address: tabithanasieku@gmail.com \\ Rosemary Wanjiku Ngugi \\ Msc Finance Student \\ School of Business \\ Department of Economics, Finance and Accounting \\ Jomo Kenyatta University of Agriculture and Technology \\ Email address: roziewanj@gmail.com
}

\section{ABSTRACT}

Financial Institutions are in the business of mobilizing and lending to borrowers and they assume various kinds of financial risks in the process of mobilizing and lending financial resources. This Theoretical study reviewed the literature to investigate the relationship between credit of information sharing and credit risk reduction in Kenya commercial banks. The literature found that the lending policy is periodically reviewed to reflect the prevailing conditions thus loan characteristics, considers an applicant's bank statements thus borrowers characteristics and the credit collection policy thus lenders characteristics before credit is advanced. The study recommends that banks should incorporate credit information sharing to reduce credit risk.

Key Words: Credit information sharing, Credit risk, Information asymmetry

\section{Council for Innovative Research}

Peer Review Research Publishing System

Journal: Journal of Social Sciences Research

Vol. 10, No. 1

editor@jssronline.com

www.jssronline.com 


\section{INTRODUCTION}

\section{Background of the Study}

Utilisation of Credit Information Sharing (CIS) has seen an increase in its use since its inception. A report by the World Bank (2009) indicates that institutionalized information sharing through private bureaus or public credit registers is utilised in more than 100 countries in the world. A research by Hunt (2012) shows that over 3 million credit reports in the USA are issued daily. Mishkin (2008) notes that developing and transition economies utilize credit registries or have fostered credit bureaus in order to boost credit growth. Introduction of credit information sharing initiative was aimed at cushioning lender form financial distress resulting from borrowers not meeting their financial obligations. Non-performing loans (NPLs) are as a result of an inability by a borrower to repay a granted credit when it falls due.

Credit markets present asymmetric information problems. Lenders do know neither the past behavior and the characteristics, nor the intentions of credit applicants. This creates a moral hazard problem that causes lenders to make credit decisions based on the average characteristics of borrowers rather than on individual characteristics (Stiglitz \& Weiss, 2008). Moral hazard implies a lower average probability of payment, making credit more expensive. Higher interest rates exacerbate another informational problem, adverse selection, because only higher risk borrowers are willing to accept loans at high interest rates (Gehrig \& Stenbacka, 2007).

Houston, Lin, Lin, \& Ma, (2010) show that information sharing mechanisms reduce adverse selection by improving the pool of borrowers, the knowledge of applicants' characteristics and therefore improve bank efficiency in the allocation of credit. Based on some case studies, Olweny and Shipho, (2011) points out that credit information sharing plays a key role in improving the efficiency of financial institutions by reducing loan processing costs as well as time required to process loan applications. Lin, Ma, \& Song, (2012) show that information sharing institutions; through their incentive effects on curtailing imprudent behavior of borrowers are also valuable in addressing moral hazard problems. In addition, they show that information sharing helps reduce average interest rates and information rent that banks can otherwise extract from their clients, reduce or even eliminate the information advantage of larger size banks and therefore should enhance credit market completion (kusa \& okoth, 2013).

It has been found out that in order to minimize loan losses thus credit risk, it is essential for commercial banks to have effective credit risk management systems in place (Basel, 2010). Given the asymmetric information that exists between lenders and borrowers, financial institutions must have a mechanism that ensures that they not only evaluate default risk that is unknown to them in order to avoid adverse selection, but also that can evolve in order to avoid moral hazards. An effective system that ensures repayment of loans by borrowers is critical in dealing with asymmetric information problems and in reducing the level of loan losses, thus the long term success of any banking organization. Credit risk management is essential in optimizing the performance of financial institutions (Basel, 2010).

\section{Credit Information Sharing and Credit Risk Reduction in Kenya}

Credit Information Sharing is the exchange of information on client financial histories (Jappelli, \& Pagano, 2010). Sharing of credit information can make an important contribution to the development of the financial system which is an important determinant of economic growth (Doblas-Madrid \& Minetti, 2009). Credit scores have immense benefits to both lenders and borrowers. Borrowers are able to negotiate with lenders on better terms. Highly rated borrowers with good credit history can convincingly negotiate for lower interest rates or even waiver of collateral.

Credit information sharing is a relatively new concept in Kenya: Banking (credit reference bureau) regulations 2008 that govern licensing, operation and supervision of credit bureaus by Central Bank of Kenya were gazetted and operationalized in 2009 (Loannidou \& Penas, 2010). Lenders can improve their knowledge about new customers through credit reference bureaus. Credit reference bureaus are information brokers that collect, file and distribute the information voluntarily supplied by their members. The Central Bank of Kenya has licensed two Credit Reference Bureaus i.e. Credit Reference Bureau Africa Limited and Metropol Credit Reference Bureau Limited (Haubrich, 2003).

According to CBK (2012) since the commencement of the Credit Information Sharing Mechanism in July 2010, all the 43 licensed commercial banks in Kenya and institutions under the Deposit Protection Fund Board continue to submit negative information to licensed CRBs within the required timeframes. Furthermore, the banks have incorporated the CIS mechanism in their credit reports from the CRBs while reviewing loan requests. The improved utilization of credit reports by banks are estimated to cut information search costs and consequently offer reasonable terms of borrowing to customers with good credit track record, CBK (2012). Credit reference bureaus gather information on the payment history and accounts of borrowers. CRBs collect and distribute two major types of data i.e. 'white' and 'black' information. 'Black' information usually refers to negative consumer data, (information about defaults on payments, delays, delinquencies, bankruptcies etc). That is, information with a negative connotation on the payment history and the financial behaviour of the data subject. White information on the other hand is positive consumer data on payment history and the financial behaviour of the data subject, credit report depends on the amount of detail of the information (La Porta, Florencio, Andrei \& Robert, 2007). 


\section{Objectives of the Study \\ General Objective}

To determine the relationship between credit information sharing and credit risk reduction in Kenya commercial banks.

\section{Specific Objectives}

The study seeks to assess the effects of information sharing based on loan, borrowers' and lenders characteristics on credit risk reduction in Kenya commercial banks.

\section{LITERATURE REVIEW}

\section{Theoretical Review}

The theoretical review models reviewed were information asymmetry, adverse selection, moral hazard, and credit rationing.

\section{Information Asymmetry Theory}

Information asymmetry describes the condition in which relevant information is not known to all parties involved in an undertaking (Ekumah \& Essel, 2003). Information asymmetry causes market to become inefficient and forces market participants to take risk because it is assumed that information which is provided is always inadequate, inaccurate, incomplete and untimely. The asymmetric information literature which looks at the impact of financial structure on economic activity focuses on the differences in information available to different parties in a financial contract.

\section{Adverse selection theory}

The adverse selection problem takes place when borrowers have private information about their personal behavior and/or the project they want to invest in, before the credit relationship begins. While the lender may have a good idea about the average characteristics of the pool of potential borrowers, he may not have full information on the characteristics of each borrower and the riskiness of his project. In order to see how the adverse selection problem arises in financial markets and how the interest rate can be used as a direct screening mechanism to differentiate the risky projects from the safe ones we assume that borrowers and lenders are risk-neutral. There are two groups of borrowers, safe and risky ones, who can choose between safe and risky projects. Both groups of borrowers have the same mean gross return but a different risk variance (Stiglitz \&Weiss, 2008).

\section{Moral Hazard theory}

Another type of information asymmetry problem is moral hazard. Moral hazard occurs in credit markets if raising the interest rate induces borrowers, who have a choice of projects, to invest in a project that yields the bank a lower return than another project in which the borrowers could have invested. Moral hazard refers to the risk that a party to a transaction has not entered into the contract in good faith, has provided misleading information about its assets, liabilities or credit capacity, or has an incentive to take unusual risks in a desperate attempt to earn a profit before the contract settles. Problems of moral hazard in banks and other financial institutions were evident at many stages of the recent financial crisis (Levine, 1997).

\section{Credit Rationing Theory}

Asymmetric information leads to credit rationing, as lenders cannot distinguish between high quality and low quality borrowers. However, this dominate view is not without criticism. In particular, De Meza and Webb (1987) vigorously contest this result. They show that asymmetric information in credit markets can lead to the inverse result, which is an excess of credit (over lending). According to Stiglitz and Weiss (2008) credit rationing still occurs if banks require collateral. They argue that low-risk borrowers expect a lower rate of return on average. Thus, they are less wealthy than high-risk borrowers on average after some periods. Low-risk borrowers are therefore not able to provide more collateral. Increasing collateral requirements may have the same adverse selection effect as a higher interest rate. 


\section{Conceptual Framework}

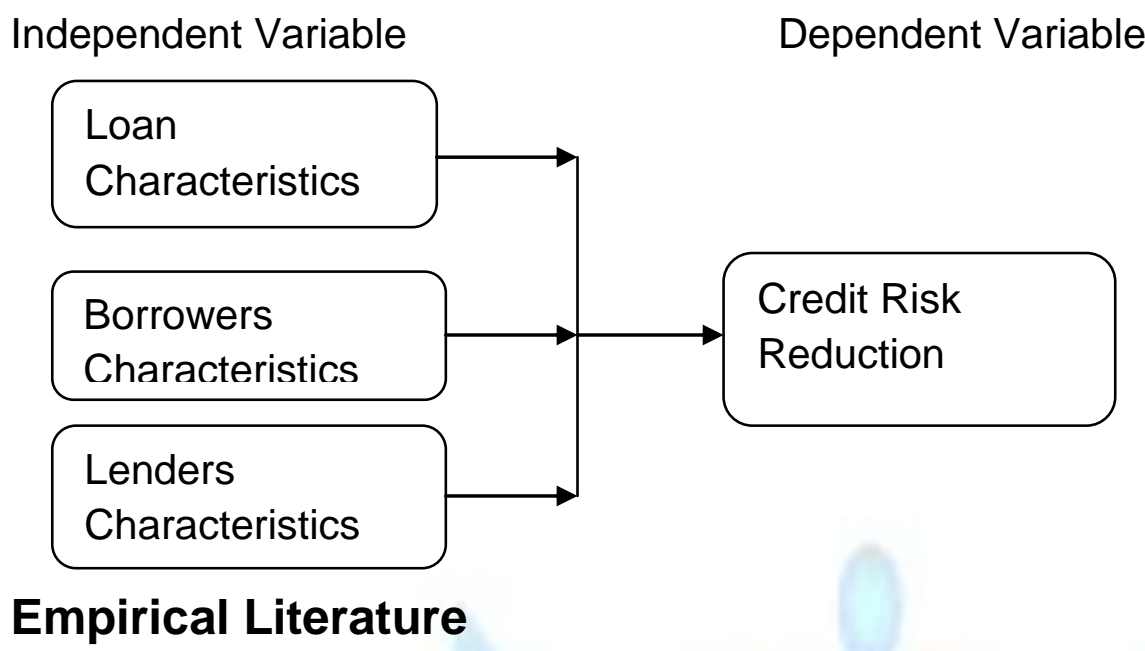

Credit information sharing improves bank knowledge about applicant's characteristics since they are confronted by large number of customers on which they have no previous information. In addition it works as a borrowers discipline device since if reputation is ruined access to credit will be cut off or will be much more expensive and thus moral hazard is reduced. Consequently information sharing tends to level the playing fields within credit market and hence force the lenders to price loans more competitively.

\section{Loan Characteristics}

Derban (2008) in their study on performing loans recovery in Ghana indicates that failure to honour financial obligation when it falls due by borrowers can be categorised into three sections: the intrinsic features of borrowers and their businesses operations. Secondly, the characteristics of the lending institution and the suitability of the loan product advanced to the borrower that makes it unlikely for repayment to occur. Systematic risk forms the third category caused by macroeconomic factors that include economic, political and business operations (Derban, 2008). In their study Roslan (2007) on poor loan repayments by small businesses in Malaysia, the study established that monitoring and early detection of problems that may arise due to the rate of portfolio default can be arrested through close and informal relationships between MFIs and borrowers. In addition, cooperation and coordination among various agencies that provide additional support to borrowers may help them succeed in their business.

Vigenina and Kritikos (2008) did a study on role of credit information sharing on credit risk reduction in Turkey which indicated that individual lending has three elements namely the demand for non-conventional collateral, a screening procedure which combines new with traditional elements and dynamic incentives in combination with termination threat in case of default, which ensure high repayment rates up to 100 percent. In a research by Saloner (2007) on poor loans repayment in Commercial banks in South Africa indicates that by increasing the loan size for a borrower, it provides an incentive for repayment of this loan on time and in full so that one continues borrowing. If an individual is able to repay progressively larger loans, it can be inferred that he is growing his business and increasing his income.

Ochola (2014) did a study on the effect of credit information sharing on the cost of credit of commercial Banks in Kenya. The purpose of credit ratings and credit information sharing is to attempt to reduce information asymmetry, reduce nonperforming loans, build information capital and generally enhance access to affordable credit in the economy. The study found that cost of funds and operating costs as factors contribute positively to the cost of credit of commercial banks while credit information sharing and credit default risk made relatively insignificant contribution to determining the cost of credit. The study recommended that cost of funds and operating costs being major determining factors in cost of loans by commercial banks in Kenya be actively scaled down so as to make credit in the country more affordable to a large customer base. Kogei (2013) did a study on the relationship between credit information sharing, loan book size and non performing loans of commercial banks in Kenya. The study revealed that there is a positive relationship between nonperforming loans of commercial banks and loan book size. The study recommended that CBK puts into place policies to ensure that it is mandatory to use credit reports for every borrower.

\section{Borrowers Characteristics}

Mpunga (2008) did a study in Tanzania on effect of borrowers' characteristics influence on credit risk, he found income levels of a business are an essential factor in the determination of the level of credit worthiness of a customer. Businesses with a high level of income have the ability to save and further utilise the excess reserves in the acquisition of loan security. Ozdemir and Boran (2008) did a study in Canada on factors affecting loan default among small business borrowers, he showed that when a loan is not repaid, it may be a result of the borrowers' unwillingness and/or inability to repay, he recommend that the banks should monitor borrowers and select the clean borrowers from defaulters and monitor them to make sure that funds are utilised for the intended reason. 
Mumi (2011) did a study in Kenya on the impact of credit referencing practices on lending in financial institutions. The findings indicated that majority of the respondents agreed that inadequate information systems concerning referencing affected market segmentation and credit referencing. The study concluded that that there was inadequate information systems' concerning referencing which affected market segmentation and credit referencing. The study recommended that financial firms should adopt adequate information sharing systems on credit referencing. Muasya (2013) did a study on the relationship between credit risk management practices and loans losses in commercial banks in Kenya. The objective of the study was to establish if there is a relationship between credit risk management practices and loan losses in commercial banks in Kenya. It was concluded that credit risk management practices are common among most of the commercial banks in Kenya. It was recommended that sound credit risk management practices are adopted and implemented especially though credit risks management information systems.

\section{Lenders Characteristics}

Godquin (2004) did a study in Nigeria on the effect of lenders characteristics on credit risk reduction among commercial banks in Nigeria. He found that the level of training, level of literacy and health services has a positive effect on the level of repayment of a financial obligation, (Godquin 2004). Hulme and Mosley (2011) did a study in India on the effect of loan design on loan repayment; he argued that the loan design features are an important factor that contributes to loan repayment. These features are categorised into three classes: access methods, screening methods and incentive to repay method. Maximum loan ceilings and high interest rate are features that access methods use to ensure that poor customers access the loans and not the richer people. Through screening methods, bad customers are identified.

Bonaya (2012) did a study on the effect of credit information sharing on loan performance of Commercial banks in Kenya. The findings were that loan performance as measured by loan default rate is negatively related to credit information sharing, lending rate and total loans. The study recommended that there should be credit information sharing in credit appraisal process since it was found to be value additive.

Munee (2013) did a study on the effect of credit information sharing on the financial performance of commercial banks in Kenya. The study used secondary data on NPLs and Credit reports shared by the CRBs with the commercial banks. The study found that sharing of credit information had led to a decrease in the Non performing loans which has an impact on the financial performance of commercial banks. The comparison of financial before and after the establishment and operationalization of credit information sharing shows an increase in the financial performance. The study recommended that the government through the relevant agencies publish credit information sharing regulations and create awareness to the public on the services available from credit reference bureaus so that borrowers can submit the relevant information to the lending institutions. The study concluded that credit information sharing has a positive effect on the financial performance of commercial banks.

\section{Summary of the Literature}

\begin{tabular}{|c|c|c|}
\hline $\begin{array}{l}\text { Topic, } \\
\text { Author(s) and } \\
\text { Country }\end{array}$ & Objectives & Findings and Recommendations \\
\hline $\begin{array}{l}\text { Determinants } \\
\text { of performing } \\
\text { loans recovery } \\
\text { in Ghana } \\
\text { Derban(2008) }\end{array}$ & $\begin{array}{l}\text { To determine the } \\
\text { factors affecting } \\
\text { performance of loan } \\
\text { recovery in Ghana. }\end{array}$ & $\begin{array}{l}\text { Failure by borrowers to honour their financial } \\
\text { obligation causes banks to lose revenue. } \\
\text { Banks should incorporate credit information } \\
\text { sharing to reduce loan default. }\end{array}$ \\
\hline $\begin{array}{l}\text { Role of credit } \\
\text { information } \\
\text { sharing on } \\
\text { credit risk } \\
\text { reduction in } \\
\text { Turkey } \\
\text { Vigenina and } \\
\text { Kritikos (2008) }\end{array}$ & $\begin{array}{l}\text { To evaluate the role } \\
\text { of credit information } \\
\text { sharing on credit risk } \\
\text { reduction. }\end{array}$ & $\begin{array}{l}\text { Demand for non-conventional collateral and } \\
\text { termination threat in case of default } \\
\text { Banks should incorporate collateral and } \\
\text { screening procedures to increase debt } \\
\text { repayment rate }\end{array}$ \\
\hline $\begin{array}{l}\text { Effect of } \\
\text { borrowers' } \\
\text { characteristics } \\
\text { influence credit } \\
\text { risk in } \\
\text { Tanzania } \\
\text { Mpunga (2008) }\end{array}$ & $\begin{array}{l}\text { To investigate the } \\
\text { effect of borrowers' } \\
\text { characteristics } \\
\text { influence credit risk. }\end{array}$ & $\begin{array}{l}\text { Business returns saved as reserve can be } \\
\text { utilised as loan security. } \\
\text { Income levels of a business are an essential } \\
\text { factor in the determination of the level of credit } \\
\text { worthiness of a customer }\end{array}$ \\
\hline
\end{tabular}




\begin{tabular}{|c|c|c|}
\hline $\begin{array}{l}\text { Factors } \\
\text { affecting loan } \\
\text { default among } \\
\text { small business } \\
\text { borrowers in } \\
\text { Canada } \\
\text { Ozdemir and } \\
\text { Boran (2008) }\end{array}$ & $\begin{array}{l}\text { To determine the } \\
\text { factors affecting loan } \\
\text { default among small } \\
\text { business borrowers. }\end{array}$ & $\begin{array}{l}\text { Loan default may be as a result of borrowers } \\
\text { unwillingness and or inability to pay } \\
\text { Banks should monitor borrowers and select the } \\
\text { clean borrowers from defaulters and utilization of } \\
\text { loan }\end{array}$ \\
\hline $\begin{array}{l}\text { The effect of } \\
\text { lenders } \\
\text { characteristics } \\
\text { on credit risk } \\
\text { reduction } \\
\text { among } \\
\text { commercial } \\
\text { banks in } \\
\text { Nigeria } \\
\text { Godquin (2007) }\end{array}$ & $\begin{array}{l}\text { To determine the } \\
\text { effect of lenders } \\
\text { characteristics on } \\
\text { credit risk reduction } \\
\text { among commercial } \\
\text { banks in Nigeria. }\end{array}$ & $\begin{array}{l}\text { The level of training on matters relating to their } \\
\text { business had a positive effect on loan default } \\
\text { Banks should analyse lenders characteristics so } \\
\text { as to reduce loan default }\end{array}$ \\
\hline $\begin{array}{l}\text { The effect of } \\
\text { loan design on } \\
\text { loan repayment } \\
\text { in India Hulme } \\
\text { and Mosley } \\
\text { (2011) }\end{array}$ & $\begin{array}{l}\text { To investigate the } \\
\text { effect of loan design } \\
\text { on loan repayment. }\end{array}$ & $\begin{array}{l}\text { Loan design features contribute to loan payment. } \\
\text { Banks should put in place maximum loan ceilings } \\
\text { and low interest rate to ensure that all access } \\
\text { loans }\end{array}$ \\
\hline $\begin{array}{l}\text { The effect of } \\
\text { credit } \\
\text { information } \\
\text { sharing on the } \\
\text { cost of credit of } \\
\text { commercial } \\
\text { Banks in } \\
\text { Kenya. Ochola } \\
\text { (2014) }\end{array}$ & $\begin{array}{l}\text { To determine the } \\
\text { effect of credit } \\
\text { information sharing } \\
\text { on information } \\
\text { asymmetry non- } \\
\text { performing loans, } \\
\text { building information } \\
\text { capital and access to } \\
\text { affordable credit. }\end{array}$ & $\begin{array}{l}\text { Credit information sharing and default rate were } \\
\text { insignificant in determining cost of credit and } \\
\text { recommended that cost of funds and operating } \\
\text { costs being major determining factors in cost of } \\
\text { loans by commercial banks in Kenya be actively } \\
\text { scaled down so as to make credit in the country } \\
\text { more affordable to the customer base at large. }\end{array}$ \\
\hline $\begin{array}{l}\text { The } \\
\text { relationship } \\
\text { between credit } \\
\text { information } \\
\text { sharing, loan } \\
\text { book size and } \\
\text { non performing } \\
\text { loans of } \\
\text { commercial } \\
\text { banks in Kenya } \\
\text { Kogei (2013) }\end{array}$ & $\begin{array}{l}\text { To determine the } \\
\text { relationship between } \\
\text { credit information } \\
\text { sharing, loan book } \\
\text { size and non } \\
\text { performing loans of } \\
\text { commercial banks in } \\
\text { Kenya. }\end{array}$ & $\begin{array}{l}\text { There is a positive relationship non-performing } \\
\text { and loan book size but a negative one between } \\
\text { credit information sharing, size of bank and non- } \\
\text { performing loans and recommended that } \\
\text { commercial use credit reports for every borrower } \\
\text { and the scope be increased to other financial } \\
\text { institutions by CBK }\end{array}$ \\
\hline
\end{tabular}




\begin{tabular}{|c|c|c|}
\hline $\begin{array}{l}\text { The impact of } \\
\text { credit } \\
\text { referencing } \\
\text { practices on } \\
\text { lending in } \\
\text { financial } \\
\text { institutions in } \\
\text { Kenya Mumi } \\
\text { (2011) }\end{array}$ & $\begin{array}{l}\text { To determine the } \\
\text { impact of credit } \\
\text { referencing practices } \\
\text { on lending in } \\
\text { financial institutions. }\end{array}$ & $\begin{array}{l}\text { Inadequate Referencing affected market } \\
\text { segmentation and credit referencing be reviewed } \\
\text { half yearly by banks and recommended that } \\
\text { financial firms adopt adequate information } \\
\text { sharing systems on credit referencing for it is } \\
\text { crucial to improve credit market performance. }\end{array}$ \\
\hline $\begin{array}{l}\text { The } \\
\text { relationship } \\
\text { between credit } \\
\text { risk } \\
\text { management } \\
\text { practices and } \\
\text { loan losses in } \\
\text { commercial } \\
\text { banks in Kenya } \\
\text { Muasya (2013) }\end{array}$ & $\begin{array}{l}\text { The objective of the } \\
\text { study was to } \\
\text { establish if there is a } \\
\text { relationship between } \\
\text { credit risk } \\
\text { management } \\
\text { practices and loans } \\
\text { losses in commercial } \\
\text { banks in Kenya. }\end{array}$ & $\begin{array}{l}\text { Negative relationship between credit risk } \\
\text { management practises and loan losses and } \\
\text { recommended sound credit risk management } \\
\text { practices are adopted more so credit risk } \\
\text { management information systems. }\end{array}$ \\
\hline $\begin{array}{l}\text { The effect of } \\
\text { credit } \\
\text { information } \\
\text { sharing on loan } \\
\text { performance of } \\
\text { Commercial } \\
\text { banks in Kenya } \\
\text { Bonaya (2012) }\end{array}$ & $\begin{array}{l}\text { To determine the } \\
\text { effect of credit } \\
\text { information sharing } \\
\text { on loan performance } \\
\text { of Commercial banks } \\
\text { in Kenya. }\end{array}$ & $\begin{array}{l}\text { Loan performance as measured by loan default } \\
\text { rate is negatively related to credit information } \\
\text { sharing, lending rate and total loans and } \\
\text { recommended that there should be credit } \\
\text { information sharing in credit appraisal process } \\
\text { since it was found to be value additive. }\end{array}$ \\
\hline $\begin{array}{l}\text { The effect of } \\
\text { credit } \\
\text { information } \\
\text { sharing on the } \\
\text { financial } \\
\text { performance of } \\
\text { commercial } \\
\text { banks in Kenya } \\
\text { Munee (2013) }\end{array}$ & $\begin{array}{l}\text { To determine the } \\
\text { effect of credit } \\
\text { information sharing } \\
\text { on the financial } \\
\text { performance of } \\
\text { commercial banks in } \\
\text { Kenya. }\end{array}$ & $\begin{array}{l}\text { Credit information sharing had led to a decrease } \\
\text { in non-performing which has an impact on the } \\
\text { financial performance and recommended that } \\
\text { the government through the relevant agencies } \\
\text { publish credit information sharing regulations and } \\
\text { create awareness on credit reference bureaus so } \\
\text { that borrowers can submit the relevant } \\
\text { information to the lending institutions. }\end{array}$ \\
\hline
\end{tabular}

\section{CONCLUSIONS AND RECOMMENDATIONS}

\section{Conclusions}

The study concludes company's lending policy is periodically reviewed to reflect the prevailing conditions thus loan characteristics had a positive impact on the rate of loan default among commercial banks in Kenya (Munee, 2013). The bank considers an applicant's bank statements before giving credit thus the study concludes that borrowers characteristics influences the rate of loan default among commercial banks in Kenya (Bonaya, 2012). The bank strictly observes the credit collection policy thus the study concludes that lenders characteristics influence the rate loan default in commercial banks in Kenya (Bonaya, 2012). The institutions reserves the right to attach customers' property in the event of default thus the study concludes that credit information sharing influences the rate of loan default among commercial banks in Kenya (Mumi, 2011). Finally the study concludes that cost of funds and operating costs as factors which contribute positively to the cost of credit in commercial banks while credit information sharing and credit default risk contribute to determining the cost of credit (Ochola, 2014).

\section{Recommendations}

The study recommends that Banks should ensure that they incorporate credit information sharing to reduce loan defaults; the study finally recommends that CBK should put into place policies to ensure that it is mandatory to use credit reports for every borrower. Commercial banks and other financial institutions should also use the information provided by CRB already licenced in Kenya to effectively to lend to potential borrowers. The government through the relevant agencies 
publish credit information sharing regulations and create awareness to the public on the services available from credit reference bureaus so that borrowers can submit the relevant information to the lending institutions.

\section{REFERENCES}

1) Basel (2010) "Principles of management of credit risk" Consultative paper issued by the Basel committee on banking supervision, Basel.

2) Bonaya, D. A. (2012). The effect of credit information sharing on loan performance of commercial banks in Kenya. Unpublished MBA paper the University of Nairobi.

3) Bouckaert, J., \& Degryse, H. (2006). Entry and Strategic Information Display in Credit Markets The Economic Journal, 116(513), 702-720.

4) Central Bank of Kenya (2008). Prudential Guidelines for Institutions Licensed under the Banking Act (Online) Central Bank of Kenya. Available: http//www.centralbank.go.ke.

5) Central Bank of Kenya (2010). Credit Information Sharing in Kenya, Nairobi Kenya.

6) Central Bank of Kenya (2012). Bank Supervision Report, Nairobi Kenya (online) available: http://www.centralbank.go.ke.

7) De Meza D.E., \& Webb, D.C., (1987). Too much investment: A problem of asymmetric information. Quarterly Journal of Economics, 102, 281-292.

8) Derban, W.K. (2008). Economic Effects of Positive Credit Information Sharing. Korea Institute of Finance, 1-2.

9) Doblas-Madrid, A., \& Minetti, R. (2009). Sharing Information in the Credit Market: Contract- Level Evidence from US Firms.

10) Ekumah, E. K., \&Essel, T. (2003). Information is power: The Problem with Credit Accesibility in Rural Banks In Ghana. University of Capetown.

11) Gehrig, T., \& Stenbacka, R. (2007). Information sharing and lending market competition with switching costs and poaching. European Economic Review, 51(1), 77-99.

12) Godquin, T. (2004). Credit information systems in less developed countries: A test with microfinance in Guatemala. Economic Development and Cultural Change, 55(2), 313-334.

13) Haubrich, R. (2003) Financial Institutions Management :A modern Perspective .Third Edition :Published by McGraw Hill.

14) Hulme, D., \& Mosley. P. (2011). Effect of loan design on loan repayment, London, UK.

15) Jappelli, T., \& Pagano M. (2010), “Information Sharing in Credit Markets: a survey", the University of Salerno: CSEF Working Paper no. 36.

16) Kogei, G. K. (2013). The Relationship Between Credit Information Sharing, Loan Book Size and Non Performing Loans of Commercial Banks In Kenya, University of Nairobi, Nairobi-Kenya.

17) Kusa, O., \& Okoth, V. (2013). Determinants of Financial Performance of Commercial Banks in Kenya. International Journal of Economics and Financial Issues. 1, 3, 237-257.

18) La Porta, R., Florencio L.S., Andrei S., \& Robert W. V. (2007). "Legal Determinants of External Finance," Journal of Finance, July $52(3), 1131-50$

19) Levine, R. (1997). "Financial Development and Economic Growth: Views and Agenda", Journal of Economic Literature 35 (2), pp.688-727.

20) Lin, C., Ma, Y., \& Song, F. M. (2012). What drives bank operating efficiency? The role of bank competition and credit information sharing. Research Handbook on International Banking and Governance, 87.

21) Loannidou, M., \& Penas, C. (2010). Credit reporting, relationship banking, and loan repayment. Journal of Money, Credit and Banking, 39(8), 1883-1918.

22) Mishkin, F. S. (2008), "Symposium on the monetary transmission mechanism", The Journal of Economic Perspectives 9, 3-10.

23) Muasya, A.M. (2013). The Relationship between Credit Risk Management Practices and Loans Losses A Study on Commercial Banks in Kenya. Unpublished MBA paper the University of Nairobi.

24) Mumi, P. O. (2011). Impact of Credit Referencing Practice in Financial Institutions in Kenya. Unpublished MBA paper the University of Nairobi.

25) Munee, T. A. (2013). Effect of Credit Information Sharing On The Financial Performance Of Commercial Banks In Kenya. Unpublished MBA paper the University of Nairobi. 
26) Mpunga .T (2008) Effect of borrowers' characteristics influence on credit risk, Vol.13 NO.3, pp.16-19.

27) Ochola, J. O. (2014). The effect of credit information sharing on the cost of credit of commercial Banks in Kenya. Unpublished MBA paper the University of Nairobi.

28) Olweny, T., \& Shipho, T. M. (2011). Effects Of Banking Sectoral Factors On The Profitability. of Commercial Banks in Kenya. Economics and Finance Review, Vol1.

29) Ozdemir, O., \& Boran, L. (2004). An empirical investigation on consumer credit default risk. Discussion Paper. Turkish Economic Association.

30) Roslan, A.H., \& Mohd Z., A. K. (2009). Determinants of microcredit repayment in Malaysia: the case of Agrobank. Humanity \& Social Sciences Journal, 4(1), 45-52.

31) Stiglitz, J. E. \& Weiss, A. (2008), "Credit rationing in markets with imperfect information”, The American Economic Review 71, 393-410.

32) Vigenina, D., \& Kritikos, A.S. (2008). The individual micro-lending contract: is it a better design than joint liability? Evidence from Georgia, Economic Systems, 28, 155-176.

33) World Bank (2009) "Doing Business in 2008: Understanding Regulation," World Bank and Oxford University Press, Washington DC.

34) World Bank. (2009). Finance for All Washington, DC: World Bank.

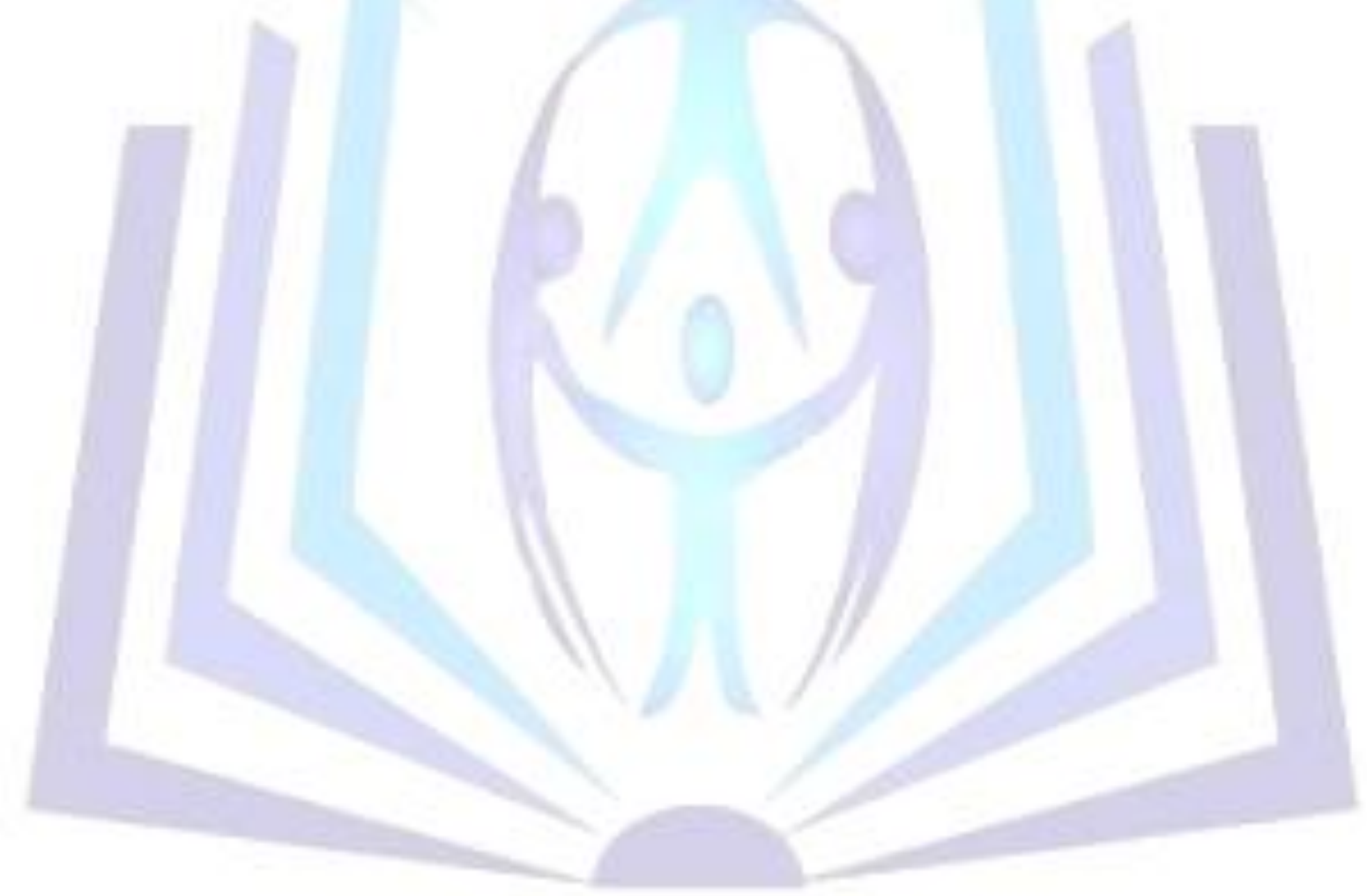

